\title{
An Overview of Strategic Management
}

\author{
Arunesh Kumar Gupta* \\ Assistant Professor, Department of Commerce, Vivekanand Mahavidyalay, Raipur, India \\ *Corresponding author: thakurnishi835@gmail.com
}

\begin{abstract}
The objective of this paper is to know about strategic management. Strategic management is an important dimension of management. Motive of this paper is to understand the meaning and level of strategies. This paper covers meaning of strategic management, how strategic management process formulate and implement for achieving goals, how strategic management plays important part in success of organization and what are the benefit of strategic management.
\end{abstract}

Keywords: Appraisal, Mission, Strategic management, Strategy, Vision.

\section{Introduction}

Present business world is full of competition every organization wants to excel in their field or we can say want to create a hagemony. Strategy gives direction to the business that organization achieve their goals strategy involves all activity and planning that help to get goal of organization. Environment of business is dynamic in nature. Environment of business makes direct impact on strategy. Word strategy is originated from Greek word strategies which means leader in army. Before 1960 strategy is used in army operations after 1960 it is used in field of management. In present age strategy making is not enough for achieving goals but strategy contain competitiveness in its nature without strategy organization cannot survive in competitions. Strategic management is all about formulation implementation and valuation of strategies strategic management includes environment scanning, strategy formulation and implementation of strategy

Objective of study:

- To know about strategic management

- To understand the benefit of strategic management process.

- To know what are the level of strategies in organization.

\section{Level of Strategy}

It is very important to know how and what levels the strategy operates.

\section{A. Corporate level Strategy}

Corporate level strategy is formulated by top level management for entire organization corporate level strategy includes following strategies.

$\begin{array}{llll}\text { Expansion } & \text { Stability } & \text { Retrenchment } & \text { Combination } \\ \downarrow & \downarrow & \downarrow & \downarrow \\ \text { Concentration } & \text { Non change } & \text { Turnover } & \text { Simultaneous } \\ \text { Integration } & \text { Caution } & \text { Liquidation } & \text { Sequential } \\ \text { Co-operation } & \text { Profit } & & \\ \text { Diversification } & & & \end{array}$

\section{B. Business level strategy}

Business level strategies are considered as the middle level in overall. These strategies are operated at business unit It can be defined as actions that requested to achieve corporate level strategies business level strategies are follows

- Cost leadership business

- Differential business strategies

- Focus business Strategies

\section{Functional level strategy}

After formulation of corporate level strategy and business level strategy strategies should be formulated in functional level functional strategies are as

- Marketing strategies

- Finance Strategies

- HR Strategies

- R\&D Strategies

- Operation Strategies

\section{Strategic Management Process (SMP)}

Strategic management process means defining the organizations strategy we can also say the strategic management process is the process by which managers make a choice of a set of strategies for the organization that will enable it to achieve better performance

Strategic management process consists four steps,

1) Establishing strategic intent

First phase of SMP is establishing strategic intent. This phase defines the vision mission business definition and business objectives. "Vision" serves the purpose of stating when an organization wishes to achieve in the long run " mission" related on organization to society " Business explains the business of an organization in term of customer need group and technologies. And "Business objective" state what is to be achieved in particular time period.

2) Formulation of strategies

After establishing strategic intent in second phase of SMP 
strategies should be formulated. strategy formulation is the process of deciding action for achieving organizations goal This phase includes performing environmental appraisal, considering corporate and business level strategies, undertaking strategic choice, formulating strategies and preparing strategic plans.

\section{3) Implementation of strategies}

This phase of SMP includes designing structure system, activating strategies and managing functional implementation. 4) Performing strategic evaluation and control

Last phase of SMP is strategy evaluation. This phase includes performance appraisal after, getting feedback from implementation of strategies. Strategies should be controlled. New Strategies can be formulated if there is any requirement and where necessary corrective action can implement by management.

\section{Benefit of Strategic Management}

Every organization works for achieving goals but there are limited resources for gaining goals. strategic management helps to achieve organizations goal by using limited resources. It helps organization to be proactive instead of reactive in shaping its future. Strategic management its future, strategic management provides framework for all major and minor decisions of organization. By using strategic management an organization can stand in front of their competitor. With the help of strategic management an organization prepare itself to face future and act as pathfinder to various business opportunities strategic management serves as corporate defence mechanism against mistake an organization can increase profitability with involvement of strategic management.

\section{Conclusion}

The above study shows meaning, process and benefit of strategic management. At present age strategic management become an important part of management in every organization has their objective and bulls without using strategic management they cannot achieve their goals and objective. it has been seen that organization that engaged in strategic management is more successful that those that do not have benefit of strategic management.

\section{References}

[1] www.managementstudyguide.com

[2] www.learnmangament2.com

[3] www.stratadecisimon.com

[4] www.strategicmanagementinsight.com

[5] www.higherstudy.org 